\title{
Strengthen Outcomes of Insurance Agent: An Exploratory Study in Pakistan
}

\author{
Muhammad Nouman Shafique ${ }^{1 *}$, Naveed Ahmad ${ }^{2}$, Haider Abbass ${ }^{3}$, \\ Raghib Manzoor ${ }^{4}$ \\ 1,3,4Scholar Preston University, Islamabad, Pakistan \\ 2Department of Business Administration , Lahore Leads University, Pakistan \\ *E-mail address: shafique.nouman@gmail.com, naveeddgk2010@gmail.com
}

\begin{abstract}
Strong relationship outcomes depend upon the combination of the relationship marketing tactics and personality traits of the customer. The proposed study will contribute to assess the relationship outcomes in insurance agent - policy holder relations in different ways; to assess the overall impact of the relationship marketing tactics on the efforts made by the firms to retain their customers with them, the overall impact of the personality traits of the customer on the customer relationship proneness, and the combine impact of the retention orientation of the customer and customer relationship proneness on the stronger relationship outcomes in the insurance industry of Pakistan.
\end{abstract}

Keywords: relationship marketing; customer retention orientation; personality traits; relationship proneness; relationship outcomes

\section{INTRODUCTION}

Relationships between supplier and customer always required to be centered in the marketing efforts by the management of every organization. However, relationships has been understand by the researchers in a better way with the development of successful relationship marketing tactics (Morgan and Hunt, 1994). After introduction of its early concepts within the industrial marketing and purchasing group in Europe (Ford, 1980), relationship marketing was introduce in the service industries (Berry, 1983) and consumer marketing also (Christy et at., 1996).

In the early period, the relationship marketing was criticized as another "Management fad" and "Emperor's new clothes" however, it has been presently acknowledged as a paradigm shift in marketing. The contemporary environment in the business has also been changed by the said paradigm shift in the marketing management with the help of relationship marketing. Therefore, relationship marketing tactics are being used by the firms to overcome the competitive advantages in the market environment. Because a mutual efforts based on trust and commitment with the help of market players allow the firms to remain competitive in the market.

The idea of relationship marketing within service industry was first time introduced by Berry in 1983 during his study of marketing in service industries. In contrast of classical 
marketing paradigm, relational marketing tactics were introduced to create the long run relationships between the customer and buyer (Gro"nroos, 1998; Vegholm, 2011; Iglesias et. al., 2011). Relationship marketing tactics are helpful to create the loyal customers, to create the word of mouth, to retain the valuable customers and to attract the new customers also (Whyatt and Koschek, 2010).

As for as related to the other basic point of the study i.e. insurance industry, with the comparison to its peers in the region, insurance industry is relatively small. Penetration and density of the insurance industry always remained modest as it compared to other jurisdictions, whereas, the insurance industry remained underdeveloped as compared to its potential. And total premium of the industry stood at over PKR124 billion as on $31^{\text {st }}$ December, 2011.

The insurance market is liberalized as totally foreign ownership. Control of insurance companies is permitted with USD4 million as paid up capital with the conditions of USD2 million in foreign exchange and the remaining amount from the local market. To remain modest as international standards, the minimum capital requirements have been reduced in a phased manner at PKR300 million for non-life and PKR500 million for life insurers.

Presently there are 39 non-life insurers including three general Takaful operators and one state owned company operating in the market whereas life insurance is being offered only by 9 life insurers including two family Takaful operators and one state owned corporation in the life insurance sector. It is further added here that $65 \%$ of the market share in gross written premium rests with the top three players. In the CY2011, non- life insurance sector grew by $16 \%$ and life insurance by $30 \%$, whereas the total premium stands at PKR54 billion and PKR\&) billion respectively.

Irrespective of these above said insurance sectors, insurance services are also being provided in health sector by two well dedicated local companies in the market along with by two foreign life insurance and by two foreign non-life insurance companies. It has been observed that new products in health, crop and livestock insurance are witnessed in the market however, new distribution channels like Bancassuranee, Web sales and Telesales has also introduced and growing up rapidly.

Keeping in view of the limitations of the study, we only discuss here the Life insurance sector of insurance industry of Pakistan. As explained earlier that demand for life insurance has been increased by 30\% during the year 2011 therefore, competition between the top players of the sector has also increased. And all the insurers are keen to satisfy and retain their customers with them. Due to the prevailing competition in the field fo life insurance, customers has become the most important strategic resources (Webster, 1994).

Increasing customer's satisfaction and maintaining long term relationship with the use customer's loyalty with the firm are highly related with the overall increasing profitability of the firm (Sweeney and Soutar, 2011). Relationship quality plays an important role to develop the customer's loyalty with the firm. According to the many studies, good quality relationship with the customer means that customers have more trust and confidence upon the selling team of the firm through achieving a continuous sense of satisfaction. Other studies regarding the relationship of relationship quality and customer's loyalty indicates that when the customer is aware about the continuous better service quality, they are willing to create a long term relationship with the firm and agree the express his trust and satisfaction about the services of selling staff (Shani nd Chalasani, 1992; Jones and Sasser, 1995).

Keeping in view of the existing competition in the life insurance sector of insurance industry of Pakistan, all organizations are entrusted to satisfy and retain their customers with them however, retention of customers depends upon many factors along with perception of 
the customers. Here the study will be conducted to investigate that how the perceptions of the policy holder having life insurance policy effects the relationship outcomes in the insurance industry of Pakistan. There are different kinds of relationship marketing tactics being used by the organizations however, to conduct the study; we only focused to measure the effect of four different relationship marketing tactics only on the perception of the policy holders.

These are as communication, after sale services, preferential treatment and tangible rewards. Process to enhance the relationships have been explained by the several previous researches (e.g., Beatty et al., 1996), however, the actual impact of the relationship marketing tactics has been measured by few (Biong and Selnes, 1995). As the all organizations remained engaged to apply different marketing tactics to enhance the customer loyalty and retention with them however, the effect of these marketing tactics always remained questionable (Sirohi et al., 1998).

The second objective of the study is to measure the effect of personality traits of the customer upon relationship proneness. There are many kind of drivers for the customer relationship proneness however; here we investigate the effect of four different personality traits of the customers only on the customer relationship proneness. These personality traits are gender, age, education level and social class of the customer. Final and the most important objective of the study is to measure the combine effect of customer retention orientation and personality traits of the customer upon the relationship outcomes.

\section{STATEMENT OF PROBLEMS}

Importance of relationship marketing has been proved by the previous researches (Rosenberg and Czepiel, 1984). Keeping in view the importance proved by the researches, the management of every organization remained engaged to apply different kind of marketing tactics to develop the customer's loyalty with the organization (Sirohi et al., 1998). But, the adoption of suitable marketing tactics are always questionable. Here in our study, we examine the effect of relationship marketing tactics on the customer's loyalty and retention of customer with the firm also.

Every customer have a different personality traits. And relationship proneness as well as relation outcomes are affected with these personality traits of the customers. Therefore, the impact of personality traits of the customer on the relationship proneness is required to be measure by the management of firms.

Strong relationship outcomes are effected with a combination of retention orientation of customer and as well as relationship proneness with the personality traits of the customers. Therefore, the relationship between these is necessarily be understand by the management.

\section{OBJECTIVES OF THE STUDY}

Strong relationship outcomes depends upon the retention orientation of the customers with the basis of relationship marketing tactics and relationship proneness with the basis of personality traits of the customer. Therefore, there are three basic objectives of our study as given here:-

To investigate the effect of relationship marketing tactics on the customer's retention orientation. 
$>$ To investigate the effect of customer's retention orientation with the basis of customer's perceptions on the relationship outcomes.

$>$ To investigate the effect of personality traits of the customer on the relationship proneness.

$>$ To investigate the effect of relationship proneness with the basis of personality traits of the customer on the relationship outcomes.

$>$ To investigate the effect of relationship proneness as personality traits of the customer on retention orientation of the customer.

$>$ To assess, how relationship outcomes can be strengthened.

\section{SIGNIFICANCE OF THE STUDY}

As the different relationship marketing tactics has their own impact on the retention orientation of the customer as well as on the relationship outcomes. Therefore, the proposed study will enable us to investigate the successful impact of relationship marketing tactics chosen by the management in insurance industry of Pakistan.

Secondly, as the strong relationship outcomes not only depends upon the efforts of firms but also on the perceptions of the individual customer. And there are significant differences in the personality traits of the customer therefore, relationship proneness effected with the basis of personality traits of the customer. Here the study will enable us to examine the effect of four personality traits of the customer on relationship proneness in service industry of Pakistan.

\section{LITERATURE REVIEW}

\section{Relationship Marketing}

The relationship marketing was initially defined as, attracting, maintaining and enhancing customer relationships (Berry, 1983). With the passage of time, a more comprehensive definition for relationship marketing was introduced as, "establishing relationships with customers and other parties at a profit by mutual exchange and fulfillment of promises" (Gronoross, 1990, Hunt and Morgan, 1994; Christopher et al., 1992; Sheth and Parvatiyar, 1995).

According to Wikstrom (1996), the role of end user to accept or reject the offer made was restricted by the transactional approach of marketing. Similarly, the emergence of Relationship marketing has been provided by different authors as, the economies of customer retention (Rosenberg and Czepiel, 1984: Reicheld and Sasser, 1990) and ineffectiveness of mass media for the use of decision making process of the customer (Copulsky and Wolf 1990; Shani and Chalasani, 1992). Despite of many reasons the emergence of relationship marketing has been changed in the market environment and they directly causes to change the relationship marketing practices.

\section{Scope of Relationship Marketing}

The scope of relationship marketing depends upon the view of relationships that a firm derived from external and internal constituencies. The scope of relationship marketing is 
developed from the relationship of six markets, namely: internal, referral, customer, supplier, influencer and employee recruitment markets (Christopher et al. 1992). As the business is a coalition of many stakeholders including employees, shareholder, suppliers, and community and as well as customers also therefore, the scope of relationship marketing is required to be extended to business - stakeholders relations.

\section{Relationship Marketing Tactics}

According to the Tseng (2007), to develop the better relations with the customers, a manager have to know the better about the factors such as market situation, database having valuable information, equipment of informing, customer's ability to use informational systems and other effective factors, because the importance of any tactics is being changed at any time and place. Following are the relationship marketing tactics chose to be used in the proposed study.

\section{Good Communication}

Communication is the ability to provide valuable and timely information. Both content and style of communication are essential to developed quality relations with the customers. According to Sheth (1975), mutual disclosure and sharing of information and ideas is also called communication.

\section{Preferential Treatment}

Preferential treatment is discriminatory treatment offered by the management between the regular and non regular customer (Wulf et al., 2001). Customer's loyalty with the product or services can become higher with the use of preferential treatment tactic (Gwinner et al., 1998). Its mean that customer will adhere to company with preferential treatment.

\section{After Sale Services}

After sale services are required to be served by the firms to satisfy their customer with the help of service centers established by the firms at different cities of the country. Firms are able to receive customer's feedback through the selected service centers and may be able to provide their products and services as per customer's demand.

\section{Tangible Rewards}

Tangible rewards are the tool to create the incentive for the seller products, distribution channels or the end user of the products with its primary goal to increase the sale of the product (Belch \& et al., 2001).

\section{Customer Retention Orientation}

We can define the customer retention orientation as, "a consumer's overall perception of the extent to which an organization effectively makes efforts to attract and retain the customers". These efforts may relate to the improvement of product or service or even to strengthen the relationship itself. However, the concept of customer retention orientation goes beyond the limited scope of salesperson's efforts. Whereas, consumer's perceptions are at the basis of customer retention orientation. 


\section{Personality Traits}

As per previous researches, it has been suggested that it is important to classify the customers engaged in the relationship (Barnes, 1997; Bendapudi and Berry, 1997). Therefore, we have included the impact of four different personality traits on consumer relationship proneness. These personality traits of the customers are as, gender, age, social class and education of the customers.

\section{Consumer Relationship Proneness}

According to the Christy et al. (1996) some buyers are intrinsically inclined to engage in relationships. And the term, "psychologically predisposed" was used by the authors to explain their idea. However, the term consumer relationship proneness is used here as a consumer's relatively stable and conscious tendency to engage in relationships.

\section{Relationship Outcomes}

Relationship outcomes included relationship satisfaction, trust and relationship commitment (Baker et al., 1999; Crosby et al., 1990; Doney and Cannon, 1997). However, attitudinal and behavioral relationship outcomes both have strong precedence in relationship marketing studies (Morgan and Hunt, 1997). In these lines, Sharp and Sharp (1997) suggested that to complement attitudinal relationship outcomes with the behavioral changes they create, underlying our choice to include an additional parameter namely buying behavior.

\section{Hypothesis for Future Studies}

Following are the hypothesis generated for the study:-

H1: A higher level of communication between insurance agent - policy holder leads towards a higher level of customer retention orientation.

H2: A higher level of preferential treatment by the insurance agent leads towards a higher level of customer retention orientation.

H3: A higher level of brand image leads towards a higher level of customer retention orientation.

H4: A higher level of tangible rewards to policy holders leads towards a higher level of customer retention orientation.

H5: A higher level of customer retention orientation of an insurance agent leads towards a higher level of customer relationship proneness.

H6: There is a relationship between gender of policy holder and customer relationship proneness.

H7: There is a relationship between age of policy holder and customer relationship proneness.

H8: There is a relationship between culture of policy holder and customer relationship proneness.

H9: There is a relationship between social clause of policy holder and customer relationship proneness.

H10: A higher level of customer retention orientation of an insurance agent leads towards the higher level of relationship satisfaction.

H11: A higher level of customer relationship proneness leads towards a higher level of relationship satisfaction. 
H12: A higher level of relationship satisfaction leads towards a higher level of trust.

H13: A higher level of trust leads towards a higher level of relationship commitment.

H14: A higher level of customer retention orientation of an insurance agent leads towards a higher level of relationship commitment.

H15: A higher level of customer relationship proneness leads towards a higher level of relationship commitment.

H16: A higher level of relationship commitment leads to increase the buying behavior in insurance industry.

Conceptual Framework for Future Studies

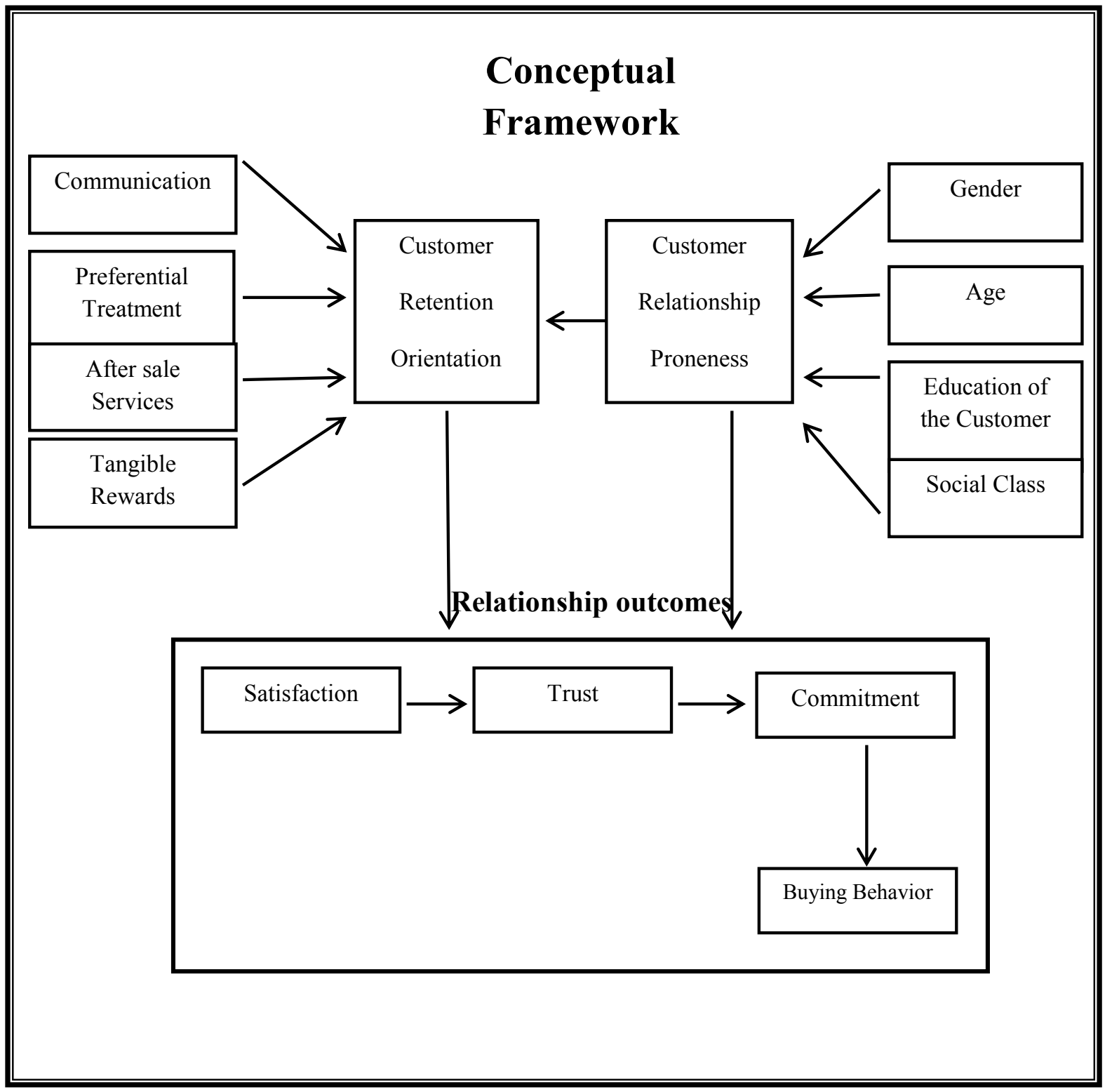




\section{CONCLUSION}

Every customer have a different personality traits. And relationship proneness as well as relation outcomes are affected with these personality traits of the customers. Therefore, the impact of personality traits of the customer on the relationship proneness is required to be measure by the management of firms.

Importance of relationship marketing has been proved by the previous researches. Keeping in view the importance proved by the researches, the management of every organization remained engaged to apply different kind of marketing tactics to develop the customer's loyalty with the organization. But, the adoption of suitable marketing tactics are always questionable. Here in our study, we examine the effect of relationship marketing tactics on the customer's loyalty and retention of customer with the firm also.

Strong relationship outcomes are effected with a combination of retention orientation of customer and as well as relationship proneness with the personality traits of the customers. Therefore, the relationship between these is necessarily be understand by the management.

\section{References}

[1] Baker TL, Simpson PM, Siguaw JA. The impact of suppliers' perceptions of reseller market orientation on key relationship constructs. J Acad Mark Sci 1999; 27:50-7.

[2] Barnes JG. Closeness, strength, and satisfaction: examining the nature of relationships between providers and financial services and their retail customers. Psychol Mark 1997; $14: 765-90$.

[3] Beatty SE, Coleman JE, Reynolds KE, Lee J. Customer-sales associate retail relationships. J Retailing 1996; 72:223- 47.

[4] Belch, G. E. \& Belch, M. A (2001); Advertising and Promotion: an Integrated Marketing Communications Perspective, Irwin/McGraw-Hill, Boston, $5^{\text {th }} \mathrm{Ed}$.

[5] Berry, L.L. (1983), Relationship Marketing Emerging Perspectives in Services Marketing, American Marketing Association, Chicago, IL.

[6] Biong H, Selnes F. Relational selling behavior and skills in long-term industrial buyerseller relationships. Int Bus Rev 1995; 4:483 - 98.

[7] Christopher, M., Payne, A. and Ballantyne, D. (1991), Relationship Marketing, Butterworth-Heinemann, Oxford.

[8] Crosby LA, Evans KR, Cowles D. Relationship quality in services selling: an interpersonal influence perspective. J Mark 1990; 54:68 -81.

[9] Doney PM, Cannon JP. An examination of the nature of trust in buyer- seller relationships. J Mark 1997; 61:35-51.

[10]Gro"nroos, C. (1998), "Marketing services: the case of a missing product", Journal of Business \& Industrial Marketing, Vol. 13 Nos 4/5, pp. 322-38.

[11] Gwinner, Kevin P., Dwayne D Gremler and Mary Jo Bitner, (1998). Relational Benefit in Service Industries: the customer perspective, Journal of Academy of Marketing Science, 26(2), 101-114, doi: 1177/0092070398262002, http://dx.doi.org/10. $1177 / 0092070398262002$. 
[12]Jones, T.O. and Sasser,W.E. Jr (1995), "Why satisfied customer defect", Harvard Business Review, Vol. 73 No. 6, pp. 88-99.

[13] Shani, D. and Chalasani, S. (1992), "Exploiting niches using relationship marketing", Journal of Service Marketing, Vol. 6 No. 4, pp. 43-52.

[14] Sharp B, Sharp A. Loyalty programs and their impact on repeat-purchase loyalty patterns. Int J Res Mark 1997; 14:473- 86.

[15]Sheth, J.N. (1975), "Buyer-seller interaction: a conceptual framework", in Anderson, B.B. (Ed.), Advances in Consumer Research, Association of Consumer Research, Cincinnati, $\mathrm{OH}$.

[16] Sirohi N, McLaughlin EW, Wittink DR. A model of consumer perceptions and store loyalty intentions for a supermarket retailer. J Retailing 1998; 74:223-45.

[17]Tseng, Yi, Ming. (2007). The impacts of Relationship Marketing Tactics on Relationship Quality in Service industry. The Business Review, Cambridge 7(2), 310.

[18]Webster, F.E.J. (1994), "Defining the new marketing concept", Marketing Management, Vol. 2 No. 4, pp. 22-31.

[19]Whyatt, G. and Koschek, R. (2010), "Implementing relationship marketing: supermarkets' perspectives", Marketing Intelligence and Planning, Vol. 28 No. 5, pp. 582-99. 